April 2007

\title{
What's in a Name? Reflections on Using, Not Using, and Overusing the "G-Word"
}

Martin Mennecke

Follow this and additional works at: https://digitalcommons.usf.edu/gsp

\section{Recommended Citation}

Mennecke, Martin (2007) "What's in a Name? Reflections on Using, Not Using, and Overusing the "GWord"," Genocide Studies and Prevention: An International Journal: Vol. 2: Iss. 1: Article 8.

Available at: https://digitalcommons.usf.edu/gsp/vol2/iss1/8

This Articles is brought to you for free and open access by the Open Access Journals at Digital Commons @ University of South Florida. It has been accepted for inclusion in Genocide Studies and Prevention: An International Journal by an authorized editor of Digital Commons @ University of South Florida. For more information, please contact digitalcommons@usf.edu. 


\title{
What's in a Name? Reflections on Using, Not Using, and Overusing the "G-Word"
}

\author{
Martin Mennecke \\ Doctoral candidate, Danish Institute for International Studies
}

\section{Introduction}

In August 1941, in a live broadcast from London, British Prime Minister Winston Churchill described the atrocities committed by Nazi troops and police under the German attack on the Soviet Union as something unprecedented: "Since the Mongol invasions of Europe in the sixteenth century, there has never been methodical, merciless butchery on such a scale, or approaching such a scale. And this is but the beginning.... We are in the presence of a crime without a name." ${ }^{1}$ A few years later, at Nuremberg, because of the lack of international legislation on this very crime, Hermann Göring and his cronies were not convicted of genocide against Europe's Jews or against the Sinti and Roma. The term "genocide" found entry into the language of only some of the indictments. In fact, as is well known to genocide scholars, the term "genocide" had first been coined in a scholarly publication in 1944, too late for the Nuremberg trials, and was introduced to international law only in 1948, when the United Nations adopted the Convention on the Prevention and Punishment of the Crime of Genocide (UNCG). ${ }^{2}$ This convention was the result of Polish jurist Raphael Lemkin's tireless lobbying of government representatives from around the world to make genocide an international crime.

Since then, the formerly nameless crime of genocide has come a long way. After a period of stagnation during the Cold War, it has been included in the statutes of the International Criminal Tribunal for the Former Yugoslavia (ICTY), the International Criminal Tribunal for Rwanda (ICTR), the Extraordinary Chambers in the Courts of Cambodia, and the International Criminal Court (ICC). Before the two UN ad hoc tribunals, numerous genocide cases have been heard, resulting in an ever-growing body of case law on the crime of genocide. In one of these cases, ICTR judges labeled genocide the "crime of crimes," a phrase often understood to mark a special status. ${ }^{3}$ Similarly, in a case concerning state responsibility before the International Court of Justice, counsel for Bosnia and Herzegovina called genocide the "super crime." In 2004, the UN secretary-general established the office of Special Adviser on the Prevention of Genocide; in 2006 he added an Advisory Committee on Genocide Prevention. In academia, Lemkin's creation of the term "genocide" has given rise to the field of genocide studies, and this field is indeed thriving: there are, as of this writing, two international associations of genocide scholars, several international journals focusing primarily on genocide research, and a fast-growing number of related university courses around the world.

Despite all these promising developments, genocide as a crime does not seem to end. There is more talk about genocide and research into genocide than ever before, and still genocide continues. Most prominently, widespread and systematic attacks on different tribal groups in the Darfur province of Sudan have over the last two years been discussed as yet another case of genocide. In fact, much time was spent on the question of whether the crimes committed against parts of the Darfuri population

Martin Mennecke, "What's in a Name? Reflections on Using, Not Using, and Overusing the 'G-Word."' Genocide Studies and Prevention 2, 1 (April 2007): 57-72. (C) 2007 Genocide Studies and Prevention. 
indeed constitute genocide; then, in the spring of 2005, the focus shifted toward obtaining the consent of the Sudanese government to the deployment of UN peacekeepers. ${ }^{5}$

It is in this context that David Scheffer puts forward two interesting proposals concerning the labeling and classification of the crime of genocide. Scheffer introduces, first, the term "precursors of genocide" to describe circumstances that could lead to genocide. The idea behind this new language is to liberate governments from "the genocide factor"- a hesitancy Scheffer believes to exist on the part of governments to apply the label "genocide" to any given situation. Scheffer posits that governments should adopt a less restrictive approach to using the term "genocide" and wants to distinguish legal, political, and historical applications of the term. Second, Scheffer develops the concept of "atrocity law," pursuant to which war crimes, crimes against humanity, and genocide-when certain criteria are met-can all be classified as "atrocity crimes." According to Scheffer, this special category of international crimes is needed to "accurately describe the totality of these crimes." 6

Scheffer's proposals are both timely and interesting. Timely because, over the past several years, much has been written about the genocide-related jurisprudence of the ad hoc tribunals but little light has been shed on the meaning of the genocide label and determination for issues of intervention and prevention. ${ }^{7}$ Equally, the description of genocide as the "crime of crimes" has found its way into many writings and speeches, but little time has been spent on contemplating the implications of such an alleged hierarchy of crimes. Scheffer's proposals are interesting because he does not give in to the usual reflex of genocide scholars to simply criticize the legal definition of genocide; instead, he attempts to increase the practical applicability of the concept of genocide to international politics. With a view to making genocide prevention more effective, this undertaking can only be welcomed.

In what follows I will not analyze Scheffer's proposals from a legal perspective (i.e., comment on the notion of atrocity law and its relation to other, existing legal categories). ${ }^{8}$ Instead, I will look at them from the perspective of genocide prevention, arguing that Scheffer's suggestion to use the formula "precursors of genocide" repeats the mistakes decision makers and scholars have made with respect to the genocide in Rwanda and the conflict in Darfur. Outside the research community, following Scheffer's advice would be counterproductive and would inadvertently keep genocide prevention in what could be called the "G-word trap"-that is, a misplaced focus on a whether a conflict is genocide or not. On Scheffer's second point, I fully endorse the concept of atrocity law as a welcome tool to reconceptualize genocide as forming part of a broader category of massive human-rights violations instead of being in its own league. I will go a step further and argue that, within the context of genocide prevention, the label "genocide" should be avoided altogether; using a term such as "atrocity crimes" would benefit attempts to prevent genocide. In conclusion, I offer some observations on how Scheffer's proposals affect genocide prevention on a more general level and what implications Scheffer's notion of atrocity law should have for the future of genocide studies.

\section{"Precursors of Genocide"}

Scheffer's first proposal deals with the terminology capturing the societal processes preceding genocide-processes that genocide scholars such as Gregory H. Stanton, as well as the UN's Committee on the Elimination of Racial Discrimination, have elaborated further. ${ }^{9}$ The group that is to be singled out as the victim group is classified, 
then discriminated against; its members lose their civil and political rights; they are dehumanized by way of propaganda and stigmatization; and so on. Scheffer reviews the practice of the Clinton administration around the Kosovo conflict in 1999 and demonstrates how the situation in Kosovo was assessed. He recalls how the formulation "indicators of genocide" was used in that connection but now prefers "precursors of genocide" as more exact and appropriate.

The real problem of genocide prevention is to identify the circumstances under which such situations escalate into genocide-and distinguishing these from situations in which they do not and any external intervention could be deemed an unjustified interference in internal affairs. Moreover, it is necessary to signal to policy makers the importance of timely action to avoid the eventual outbreak of genocidal violence. International politics are geared more toward crisis management than toward prevention and early warning. The formula "precursors of genocide" thus addresses a complex political issue and is not a term governments easily will adopt and use. As a former senior official within the US State Department and former US ambassador-at-large for war crimes issues under the Clinton administration, Scheffer is only too aware of this. It is his hope that the proposed language of "precursors of genocide" can free governments from the fear of prematurely labeling a conflict "genocide" and thus lead the way to effective early warnings and genocide prevention.

The term "precursors of genocide" seems, at first sight, a useful and accurate description of the process leading up to a genocide. Given Scheffer's experience with the Clinton administration, in particular his work heading the US government's Atrocities Prevention Inter-Agency Working Group, one is inclined to believe that the "precursors" formula may also be a working tool well suited for genocide prevention in the political context. Currently, both politicians and media often distinguish only between "genocide" and "not genocide," thus missing out on the basic fact that genocide is a process that includes "before," "during," and "after"-three essential, but not always clearly distinguishable, phases. The suggested formula does not focus on whether genocide is occurring or not, leading to a time-consuming and complex discussion of evidence, but focuses on the phase preceding genocide.

\section{New Language Where a Paradigm Shift Is Needed}

Upon closer scrutiny, however, Scheffer's proposal, for several reasons, falls short of bringing progress to the field of genocide prevention. In fact, following his suggestion would make things worse, which would be contrary to his intentions and would lock states into the "G-word trap." The proposal is based on incorrect and partly outdated assumptions, and, above all, it retains the focus on the term "genocide" instead of shifting focus away from it. In light of the most recent experiences with the Darfur crisis, genocide prevention needs not new language but a paradigm shift.

\section{The "G-Word" Has Come of Age-But It Has Also Lost Its Power}

Scheffer bases his proposal on two assumptions: that states and other relevant actors have a hesitancy to use the genocide label, and that genocide prevention would become more effective if states altered this attitude and used that label more freely. Scheffer's view echoes earlier writings about the international community's, and in particular the US government's, response to the Rwandan genocide in 1994. At that time government representatives went to great lengths to avoid using the term "genocide," fearing that a genocide determination would impose a legal obligation on all parties 
to the UNCG to stop that particular genocide. ${ }^{10}$ As a consequence, genocide scholars and non-governmental organizations active in the field of genocide prevention began to put great effort into labeling ongoing conflicts as genocides (when deemed appropriate). The hope was that the "G-word" would create public attention, exert moral pressure, and impose a legal obligation on Western governments to take action to stop the genocidal violence. ${ }^{11}$

Times (and legal views) have changed, however. More than ten years later, facing massive human-rights violations in Darfur, several governments and parliaments, and, above all, the US administration, repeatedly and early on referred to the situation as "genocide." 12 The assumption underlying Scheffer's proposal-that states need to be "liberated from the genocide factor" to use the term "genocide" more often in order to make genocide prevention effective-is no longer valid; states have in fact begun to use the term genocide, as it no longer bears the stigma of legal obligation. The sense of a moral obligation has also faded with the general decrease in support for sending troops to improve human-rights situations in distant countries. The only place where the "G-word" seems to retain an aura of moral superiority (for those accusing others of genocide) is within domestic politics, as seen, for example, in the United States, where there is an active civil society and journalists-such as Nicholas Kristof of the New York Times - who are concerned with genocide prevention. This movement in the United States, however, has not had a similar counterpart in Europe. States can therefore afford a "more liberal approach" to the "G-word" without risk of becoming engaged in an armed intervention. This new outlook on the meaning of the "G-word" became crystal clear in the statement made by Colin Powell, then US secretary of state, to the US Senate announcing the results of an investigation into the crimes committed in the Darfur region: "The evidence leads us to the conclusion, the United States to the conclusion, that genocide has occurred and may still be occurring in Darfur [...] In fact, however, no new action is dictated by this determination." 13

In addition, the Darfur crisis has shown that the use of the "G-word" is not equivalent to actual action on the ground. At the time of writing, it has been more than two years since the US government declared the government of Sudan guilty of genocide; in fact, it is more than three months since the UN Security Council adopted a resolution sanctioning the deployment of about 20,000 UN forces to the Darfur region-and still the government of Sudan pursues the same policies and rejects the sending of UN peacekeepers. The use of the "G-word" in the Darfur crisis has neither helped galvanize broad international support for action to stop the killings nor forced the Sudanese government to halt its campaign of ethnic cleansings. There appears to be very little evidence that using the "precursors of genocide" formula with respect to the next Darfur would change the fact that the "G-word" has lost its power.

\section{Using the "G-Word" Generates Additional Problems}

Having noted that the use of the term "genocide" (or of any related phrases, such as "precursors of genocide") not only does not contribute to the prevention of genocide, but actually gives rise to a number of additional problems. It is these problems that turn Scheffer's proposal from merely failing to strengthen genocide prevention to being counterproductive. This section highlights a few examples of these implications of the "G-word."

As we saw above, several actors have, during the Darfur crisis, displayed a revised-in Scheffer's terminology, more "liberal"-approach to the term "genocide." This, however, should not create the impression that, in the future, more government 
statements and press releases will necessarily use the term. This has less to do with uncertainty about whether the evidence meets the requirements of the UNCG than with the inevitably political character of such a statement. While Scheffer advocates distinguishing between legal and political uses of the term "genocide," in international political institutions such as the UN Security Council or the African Union (AU), few will be able to appreciate the nuances of this approach-one need only think of the state being accused of genocide, or of those traditionally keen on maintaining a conservative reading of concepts such as sovereignty, including China, Russia, and certain African states. In international politics, the "G-word" will remain a very serious allegation to make against a foreign government-and this would likely be equally true for any allegation that "precursors of genocide" are present on the territory of a given state. ${ }^{14}$ This is something to consider, in particular, in a situation in which those concerned with genocide prevention intend to ameliorate the situation by sending UN peacekeepers to the country in question. Such deployment requires, pursuant to chapter 6 of the UN Charter, consent by the relevant host state. Both allegations of genocide and remarks pointing to "precursors of genocide" may render this consent very unlikely.

The way the Darfur crisis has evolved serves as an example. It should be recalled that the government of Sudan has, up to this point, opposed all efforts to replace the understaffed and under-equipped AU contingents with a stronger UN force, calling such attempts an effort to "recolonize" the Sudan. ${ }^{15}$ The UN Security Council's resolution of 31 August 2006, which outlines the replacement of the AU forces by UN troops, does not mention either "precursors of genocide" or genocide-instead the Security Council speaks of "its strong condemnation of all violations of human rights and international humanitarian law in Darfur." 16 This is, on the one hand, a concession to countries such as China and Russia, who might otherwise have vetoed this resolution; but the omission of any reference to the term "genocide" is also necessary to negotiating with the government of Sudan to try to gain its acceptance of a UN mission to Darfur. The term "genocide," following the US determination, led to a UN commission of inquiry into the same question; since the commission's report to the United Nations that no genocidal policy could be documented, the "G-word" has played no role on the international scene. ${ }^{17}$ All players, including the US government, have subsequently referred only a few times to "genocide." This may be decried as inaccurate, or even shameful and dishonest; but as long as a humanitarian intervention of the kind launched in Kosovo in the spring of 1999-circumventing the UN Security Council and leaving aside the opposition of Russia, China, and a number of African countries-remains an option discussed only in editorials and letters to the editor, the "G-word" has only a minor role to play in the international arena.

The use of the term "genocide" by different actors outside the United Nations during the Darfur conflict has brought an additional issue to the forefront. The independent determination of genocide by the US government in September 2004 made it evident that unilateral actions-regardless of their intentions-are easy targets for political attacks, undermining the credibility and potential effect of any such determination. ${ }^{18}$ The UNCG lacks a standing mechanism to survey violations of the prohibition against genocide, but art. 8 reminds member states of the option to turn to "relevant UN organs," such as the Security Council, to take action. Nowhere does the convention envisage that a member state might establish its own commission to examine whether genocide is occurring in another member state. ${ }^{19}$ 
In this case, both the Sudanese government and the Arab League denounced the US finding as political propaganda. ${ }^{20}$ This will inevitably also be true of any future unilateral assertions that "precursors of genocide" can be found in a given country; it is much more difficult, however, to denounce the results of international fact-finding commissions. ${ }^{21}$ Admittedly, the government speaking of "precursors of genocide" would not face the same burden of proof as the state declaring that genocide has occurred; but this is also the soft spot of using the formula "precursors of genocide" as a foreign-policy tool: the regime responsible for the situation in question can even more easily refute the allegations as unfounded and pure political spin. Scheffer's proposal, intended to make genocide prevention more effective by lowering the threshold for using relevant language, would in practice, in the case of a regime like the government of Sudan, turn out to be self-defeating.

\section{In the Interests of Preventing Genocide: Drop the "G-Word"}

Given the original focus of the UNCG on prevention and punishment of the crime of genocide, it is ironic that the term "genocide" has evolved to become a stumbling block to genocide prevention. In the case of Darfur, much focus and energy was wasted, in the first half of 2004, on discussing whether or not the conflict fell under the terms of the UNCG. Politicians and the media engaged in intense debate over the "G-word," while the victims of the violence continued to suffer and to wait for help. ${ }^{22}$ Scheffer's proposal would keep states locked in this futile debate with respect to future conflicts, as the focus in the political reality will be not on "precursors"-which could serve as an important reminder of the fact that prevention can, and should, start long before the actual mass violence is unleashed-but on "genocide." It does not take much political genius (at least, not after the endless discussions about the Darfur conflict) to predict that future conflicts would yield similar debate over whether it is appropriate and justified to speak of "precursors of genocide."

This debate is not only a waste of time when the situation demands quick, decisive action to protect potential victims; it is also unnecessary, in light of recent developments in the field of humanitarian intervention. According to the "Outcome Document" of the UN World Summit of September 2005, which has since been confirmed by a resolution in the UN Security Council, all states have a responsibility to protect the civilian population of their own territory from war crimes, crimes against humanity, and genocide, and, in cases where the state in question fails to act as necessary, the international community has a responsibility to do the same. ${ }^{23}$ No distinctions are made among these different crimes. The same is true for the provisions of the UN Charter authorizing the Security Council to mandate peacekeeping missions and of the Charter of the African Union, which explicitly allows the AU to intervene in other member states when there are war crimes, crimes against humanity, or genocide. ${ }^{24}$ For this reason, when considering external intervention necessary to stop a situation from developing into genocide, genocide scholars and the media should drop all focus on the "G-word," rather than discussing whether certain actions could be classified as "precursors of genocide."

Scheffer asserts that during the Kosovo conflict the then-current formulation "indicators of genocide" ended the media discussion of whether or not genocide was occurring in Kosovo. Recall, however, that this discussion became moot because NATO decided to intervene with force-and did so without the authorization of the UN Security Council. The question of whether genocide was in the making became, for some time, beside the point. ${ }^{25}$ It should be recalled also that the spring of 1999 
provided a case study of how easily the term "genocide" can be politically instrumentalized within Western democracies. In Germany, for example, leading members of the government spoke of genocide with a view to build public support for the planned NATO operations. ${ }^{26}$ Scheffer's call for "liberating governments from the genocide factor" should also be weighed carefully in light of these recent experiences.

\section{Interim Conclusion}

Scheffer's proposal to use the formula "precursors of genocide" must be rejected. This rejection is not based on what the proposal tries to achieve; clearly it has its academic merits and is based on good intentions. It fails to convince, however, in terms of policy making, as it does not take into account the international response to the Darfur crisis, and therefore it cannot help to make genocide prevention more effective. The idea of distinguishing between legal, political, and historical applications of the "G-word" remains academic; instead we must realize that the "G-word," in many cases, will be a non-starter for effective genocide prevention. The "G-word" has an important role to play when individual perpetrators are being brought to justice, but its role is far more minor when it comes to generating international support for peacekeeping operations or UN-authorized humanitarian interventions. It is Scheffer's own concept of "atrocity crimes"-his second proposal-that implements this insight and points the way toward accomplishing what really is at stake. Colin Powell put it this way in his testimony before the US Senate:

Let us not be too preoccupied with this [genocide] designation. These people are in desperate need and we must help them. Call it civil war; call it ethnic cleansing; call it genocide; call it "none of the above." The reality is the same. There are people in Darfur who desperately need the help of the international community. ${ }^{27}$

\section{"Atrocity Law"}

After 1994, many genocide scholars and activists viewed the failure to label the mass killings in Rwanda as genocide as symbolic of the failure to intervene and stop the killings. More and more emphasis was placed on using the term "genocide," and failure to do so was branded "denial." In 2004, the United States and other actors did call the Sudanese government's campaign in Darfur genocide-and those not using the "G-word" were attacked as deniers. ${ }^{28}$ But even after the US determination of genocide, nothing much has happened on the ground. The situation of the people of Darfur remains critical.

The lesson of Rwanda and Darfur-of the way the "G-word" was initially dodged, only to be used later without serious or effective follow-up-is not that another time around, witnessing yet another atrocious conflict, even more actors should label, or should be urged to label, a given conflict "genocide." The lesson, rather, is that the genocide label can no longer be seen as a decisive step toward action to stop mass killings. Labeling does not do it. Instead, a fresh look is needed. What terminology should be used, by genocide scholars and others, when there are massive human-rights violations and a quick and effective response is needed from the international community? It is in this context, and taking into account the lengthy discussions about genocide and the lack of response to Darfur, that we need to assess Scheffer's second proposal.

Here, Scheffer suggests placing genocide within a larger category of crimes that also includes war crimes and crimes against humanity when these fulfill certain 
conditions, which he outlines in more detail. This category of crimes Scheffer calls "atrocity crimes." 29 Scheffer remarks that the only answer to all questions on whether or not a given conflict constitutes genocide should be, "We don't care!"30 Only this second proposal, however-the notion of atrocity law-draws this consequence of the issues surrounding the use of the "G-word"; Scheffer's suggestion to speak of "precursors of genocide" does not. For a number of reasons, Scheffer's "atrocity crimes" constitute a welcome addition to the terminology of genocide studies.

First of all, speaking of "atrocity crimes" may help to ensure that international attention, be it from media or from scholars, is not overly focused on conflicts that are being discussed as "genocide." Because what is in a name? It is difficult to grasp why the enormous war in the Democratic Republic of Congo (DRC) has generated so little interest, not to speak of response, in the mainstream media and among non-governmental organizations in both North America and Europe. Several million people are thought to have been killed in or because of the war in the DRC, while the conflict in Darfur, over the last three years, has killed perhaps 400,000. Indeed, suffering should not be measured in numbers; but neither should suffering be measured in labels. This is as true for the DRC as for Darfur: international action should not depend on a genocide determination. ${ }^{31}$ Scheffer's notion of "atrocity crimes" may help to overcome the existing focus on genocide.

Moreover, the concept of "atrocity crimes" may help to rid discussions in political forums of the everlasting question of genocidal intent-and thus take the discussion away from the lawyers. ${ }^{32}$ The UNCG stipulates a very high threshold for genocide: that the perpetrator had the intent not only to carry out the acts described in the legal definition of genocide but to do so with a view to destroy, in whole or in part, the group to which the victims belong. The trials before the ICTY, in particular, have shown what great challenges this requirement of intent can pose in terms of evidence-and there is no need to confront policy makers with this discussion when they are deciding on the feasibility of, for example, a military intervention. International law, as it stands, allows for UN-authorized interventions and, arguably, for unauthorized humanitarian interventions regardless of whether genocide or "only" ethnic cleansing or other crimes against humanity are being committed. To speak of "atrocity crimes" in this connection helps to refocus the debate on the fact that widespread and systematic human-rights violations are being committed. Their specific legal classification can and should be left to judges and be dealt with outside the forums where political measures to stop the crimes are discussed and decided. ${ }^{33}$ This should also be done to ensure that the argument for intervention is not weakened by a debate over whether or not a conflict is genocidal. Interestingly, the debate on whether or not genocide was being committed in Darfur also died down after the UN Commission of Inquiry's statement that it could not determine an overall genocidal policy but recommended that the International Criminal Court (ICC) examine this and other questions of individual accountability more closely. After the UN Security Council referred the Darfur situation to the ICC in March 2005, almost all international actors adopted language indicating that the exact determination was up to the Court. ${ }^{34}$ This changed the dynamics from, in a way, voting on the question of whether genocide was being committed to acknowledging that this question was best placed with a tribunal.

Another reason to use the term "atrocity crimes" is that it, better than the existing terms, captures what is actually happening to the people on the ground. Dictionaries define "atrocity" as a brutal or barbarous act, and thus the term "atrocity" appears immediately meaningful also to the non-expert and non-lawyer. ${ }^{35}$ It also is free of any 
tendency to avoid naming crimes such as rapes and killings as the crimes they are; this remains more questionable with terms used by some governments with respect to Darfur, such as "humanitarian disaster"-which remind one of natural disasters rather than accurately describing the reality on the ground in Darfur. "Genocide" is an artificial word; it is not self-explanatory and is understood very differently not only among experts but, in particular, among non-experts and the general public. Some view the Holocaust as the only genocide; others speak of the killing of animals for food production as genocide. The same lack of clarity exists among the general public about the term "crimes against humanity." It is not clear to everybody why the killing of some tribes in a hitherto unknown province of Sudan should be considered a crime against humanity, thus also affecting citizens of Europe or North America. On this notion of humanity and its universal membership, Michael Ignatieff once made a poignant observation when reciting a scene from Claude Lanzmann's film Shoah. In this scene, a Polish peasant is asked what it meant for him that there was a concentration camp bordering his fields. He answers, "When I cut my finger, I feel it. When you cut your finger, you feel it." 36 The term "atrocity crimes" does not require us to feel that we are part of some universal entity called "humanity"; it does not require that we all subscribe to some notion of liberal universalism. The term "atrocity crimes" will not do away with all these issues, but it will add a sense of clarity.

To speak of genocide, some may interject, also sends a clear message. This may be true in one way, but it also is important to note that labeling the situation in Darfur, or any other situation, as "genocide" may be an oversimplification. Genocide is associated with (and in some instances, such as the genocide definition of Frank Chalk and Kurt Jonassohn, defined as) a form of one-sided killing. ${ }^{37}$ This is, of course, an accurate description of the character of the crime of genocide and is important to remember. Sometimes, however, genocide occurs against a background of armed conflict, and this requires the observer to check carefully whether certain factions within the victim group also commit crimes. ${ }^{38}$ To understand the current crisis in Darfur and to design a solution to the underlying conflict, it is crucial to take note of the crimes committed by some of the various and different Darfuri rebel groups. ${ }^{39}$ The term "atrocity crimes" has the advantage of referring to human-rights violations in plural-leaving the door open for a more nuanced picture of the conflict in question. When discussing the deployment and mandate of a UN peacekeeping force, this may prove of crucial importance.

In conclusion, Scheffer's proposal is to be welcomed as a timely and needed addition to the discourse on preventing and intervening in genocide. It will, of course, take some time to make this term part of the common discourse in the media and among decision makers, but genocide scholars and relevant non-governmental organizations can influence this process. ${ }^{40}$ At one time "genocide," too, was a completely new creation; more recently, the concept of a "responsibility to protect" has made its way within a few years from a report commissioned by the Canadian government into UN documents and diplomatic language. Genocide scholars should begin disseminating the insight that "what matters is not the "G-word" but the "A-word"-atrocity crimes." 41

\section{Looking Ahead: Genocide Prevention after Darfur}

"Just calling it genocide does not open a magic box-but it raises the moral and political stakes. You can't just say it's genocide and then not get involved." ${ }^{2}$ This remark was made by Jerry Fowler, director of the Committee of Conscience 
at the US Holocaust Memorial Museum, the day before the US government made its genocide determination. Most people thought that way back in September 2004-and were proven wrong. The conflict in Darfur has been labeled a genocide, and nothing much has happened since.

For the reasons outlined above, Scheffer's notion of "atrocity crimes" constitutes a chance to move on from the shock of the Darfur determination and the subsequent lack of action for those working on genocide prevention. "New conceptions require new terms," Lemkin wrote when introducing his own concept of genocide, and that is what "atrocity crimes" does. ${ }^{43}$ The concept challenges genocide scholars to question their existing focus on deciding whether or not a conflict is genocide, as it compels them to revisit some of the existing truths about genocide prevention. Clearly, less energy should be put into fighting and denouncing "deniers" of the "genocide" in Darfur and elsewhere, when the main objective is to stop ongoing killings and to galvanize support for an effective international response. A starting point for this work could be a closer look at the mandate of UN Special Adviser on the Prevention of Genocide Juan Méndez: ${ }^{44}$ he is not to make genocide determinations. This is striking-and it makes sense, not least because it gives the adviser a much broader mandate than to focus only on actual cases of genocide.

In 2002, Samantha Power wrote on the value of the "G-word" that "still, Lemkin's coinage has done more good than harm." 45 The question is whether this assessment remains true after the tiring discussions regarding Darfur. In any case, it seems time to limit the use of Lemkin's concept of genocide to research and trials, while the political work of prevention and intervention should make a fresh start-and it should do so on the basis of the concept of "atrocity crimes," as proposed by David Scheffer.

\section{Acknowledgments}

The author thanks Jesper Houborg for research assistance and the foreign ministries of Australia, Ireland, Italy, New Zealand, Norway, South Africa, Sweden, the United Kingdom, and the United States; the European Union; and a number of nongovernmental organizations, in particular Amnesty International and International Crisis Group, for their kind assistance in locating relevant material on how all these actors have responded to the question of whether or not the Darfur crisis can be classified as genocide. The relevant correspondence, quoted throughout the article, is on file with the author.

\section{Notes}

1. See Leo Kuper, Genocide: Its Political Use in the Twentieth Century (New Haven, CT: Yale University Press, 1981), 12. See also James T. Fussell, “'A Crime without a Name': Winston Churchill, Raphael Lemkin and the World War II Origins of the Word 'Genocide"' (Prevent Genocide International, n.d.), http://www.preventgenocide.org/genocide/crimewithoutaname. htm (accessed 3 January 2007).

2. Convention on the Prevention and Punishment of the Crime of Genocide, 9 December 1948, 78 U.N.T.S. 277. The UN General Assembly had already passed, on 11 December 1946, a resolution concerning genocide (UN GA Res. 96-I), but the drafting of the UNCG was completed in 1948, and in 1951 a sufficient number of states had ratified the convention for it to enter into force.

3. Prosecutor v. Kambanda, Judgment and Sentence, ICTR-97-23-S (4 September 1998), para. 16. The judgment explains that "regarding the crime of genocide, in particular, the preamble to the Genocide Convention recognizes that at all periods of history, genocide has inflicted great losses on humanity and reiterates the need for international cooperation 
to liberate humanity from this scourge. The crime of genocide is unique because of its element of dolus specialis (special intent) which requires that the crime be committed with the intent to destroy in whole or in part, a national, ethnic, racial or religious group as such, as stipulated in Article 2 of the Statute; hence the Chamber is of the opinion that genocide constitutes the crime of crimes."

4. Bosnia and Herzegovina v. Serbia and Montenegro, verbatim record of the oral pleadings, International Court of Justice (1 March 2006), para. 34 (M. Franck): "It is that terrible pattern which, ultimately, transforms many ordinary crimes into over-arching and undeniable genocide. It is the accumulation of solitary crimes, the dreadful repetition of evil acts that emerges finally, clearly, as the super crime of genocide."

5. For an elaboration of how the massive human-rights violations in Darfur have been studied and discussed, but not acted upon, see Eric Markusen, "Genocide in Darfur: Studied, But Not Stopped," African Renaissance (2006): 43-51.

6. David Scheffer, "Genocide and Atrocity Crimes," Genocide Studies and Prevention 1 (2006): 229-50, 238.

7. The first issue of Genocide Studies and Prevention, for example, carries a number of highly interesting articles on the Darfur crisis. Most of them acknowledge the debate over the "G-word," but they do so only in passing. There is no substantial discussion of the implications of this "G-word" debate for genocide studies in general or for genocide prevention in particular.

8. Other contributions to this special issue do discuss in depth the legal implications of Scheffer's proposals. A first look suggests that some refinement is needed, as Scheffer asserts, for example, that his notion of atrocity law corresponds to the jurisdiction of most of the recently established international or semi-international tribunals. This is incorrect, given that courts such as the Special Court for Sierra Leone and the Extraordinary Chambers in the Courts of Cambodia also have specific national crimes in their respective statutes.

9. See Gregory H. Stanton, "The Eight Stages of Genocide" (Genocide Watch, 1998), http://www.genocidewatch.org/8stages2006.htm (accessed 3 January 2007); Committee on the Elimination of Racial Discrimination (CERD), Decision on Follow Up Procedure to the Declaration on the Prevention of Genocide: Indicators of Systematic and Massive Patterns of Racial Discrimination, UN Doc. CERD/C/67/Misc. 8 (19 August 2005), http://

www.ohchr.org/english/bodies/cerd/docs/CERD.C.67.Misc.8.pdf (accessed 3 January 2007).

10. The infamous highlight of this concerted effort to avoid the "G-Word" was a press conference at the US State Department on 10 June 1994, during which spokeswoman Christine Shelly tried to explain to the press why the killings in Rwanda constituted "acts of genocide" but not "genocide." See US Department of State, Daily Press Briefing (10 June 1994), http://dosfan.lib.uic.edu/ERC/briefing/daily_briefings/1994/9406/940610db.html (accessed 3 January 2007).

11. See, e.g., Kenneth J. Campbell, "The Role of Individual States in Addressing Cases of Genocide," Human Rights Review 5 (2004): 32-45, 38. For a more critical view see Gerard Prunier, "The Politics of Death in Darfur," Current History 105 (2006): 195-202, 201.

12. The US determination came on the basis of data collected by the Atrocities Documentation Team; for more information, see Samuel Totten and Eric Markusen, eds., Genocide in Darfur: Investigating the Atrocities in the Sudan (New York: Routledge, 2006). See US Department of State, Documenting Atrocities in Darfur (21 September 2004), http://www.state.gov/g/drl/rls/36028.htm (accessed 3 January 2007). Colin Powell, then US secretary of state, announced the determination of genocide on 9 September 2004 in front of the US Senate's Foreign Relations Committee. Colin L. Powell, Testimony before the Senate Foreign Relations Committee, 9 September 2004, http://www.state.gov/secretary/ former/powell/remarks/36042.htm. Other governments and international actors followed, including the Swedish government, the European Parliament, and, much later, the French foreign minister. See, for example, the resolution of the European Parliament on the 
humanitarian situation in Sudan, of 16 September 2004, http://www.europa-eu-un.org/ articles/en/article_3810_en.htm (accessed 17 January 2007), speaking of the violence in Darfur being "tantamount to genocide." A step further went the Joint Parliamentary Assembly of the African, Caribbean, and European Parliamentarians in the joint resolution Sudan: ACP-EU Underline "Unprecedented Genocide" in Darfur, 22 June 2006, http://www.europarl.europa.eu/intcoop/acp/60_11/pdf/press/thursday.pdf (accessed 17 January 2007), speaking of an "unprecedented genocide" taking place in Darfur.

13. Powell, ibid.

14. For example, the foreign ministry of Luxemburg, which from 1 January to 30 June 2005 had the presidency of the European Union, acknowledged that "the use of an accurate term to define the happenings on the ground [in Darfur] has indeed been discussed at great length. It was retained at the time that the term 'genocide' would not be used in official statements or documents." Foreign Ministry, Luxembourg, e-mail to author, 23 October 2006. Amnesty International has also issued internal guidelines on how and when to use the "G-word."

15. See Nick Wadhams, "Sudan Won't Accept UN Peacekeepers," Washington Post, 19 September 2006.

16. UN Security Council Resolution 1706, UN Doc. S/RES/1706 (31 August 2006), Preamble, para. 8.

17. Report of the International Commission of Inquiry on Darfur to the United Nations Secretary-General (25 January 2005), http://www.un.org/News/dh/sudan/com_inq _darfur.pdf (accessed 3 January 2007).

18. In the case of the US determination, furthermore, it was not helpful that the US government published only an eight-page brochure to document its genocide determination, even though more than twenty investigators had interviewed more than 1,000 refugees at several camps in eastern Chad. It also weakened the case of the US government that it did not provide a legal analysis of the data. See US Department of State, Documenting Atrocities in Darfur (Washington, DC: Bureau of Democracy, Human Rights and Labor and Bureau of Intelligence and Research, 2004), http://www.state.gov/g/ drl/rls/36028.htm (accessed 17 January 2007)).

19. Given the current political climate in the Middle East and the persisting discussion about double standards, it would not come as a surprise if, at some point in the future, some country should form a commission to "examine" whether or not Israel is committing genocide against the Palestinians. As a warning sign in this connection, note that the newly established UN Human Rights Council, during its first meetings in 2006, did not address the situation in Darfur but did examine Israel at great length. At the fourth special session, on 13 December 2006, the Human Rights Council at last discussed Darfur and decided to "dispatch a High-Level Mission to assess the human rights situation in Darfur"; see Human Rights Council, Situation of Human Rights in Darfur, Decision S-4/101, http://www.ohchr.org/english/bodies/hrcouncil/specialsession/4/docs/S-4.101.pdf (accessed 3 January 2007).

20. See, e.g., "Statement by $\mathrm{t}[\mathrm{h}] \mathrm{e}$ Sudanese Ministry of Foreign Affairs on the Remarks Made by the U.S. Secretary of State on the Situation in Darfur (21 September 2004), http://www.embassysudanindia.org/news/21sep04.html (accessed 3 January 2007).

21. International fact-finding commissions backed by the UN Security Council have recently carried out their work in both Lebanon and East Timor. In both cases, despite a highly sensitive mandate and a highly politicized environment, these international inquiries have yielded results that formed a useful basis for subsequent political actions. See, for further references, "Lebanon and Syria" (Global Policy Forum, 2006), http://globalpolicy.igc.org/security/issues/lbisindx.htm (accessed 3 January 2007). It could be argued that the unilateral US inquiry into the genocide question was needed to pave the way for a UN commission. For this view, and an inspired defense of the Atrocities Documentation Project, see Samuel Totten, "The US Investigation into the Darfur Crisis and the US Government's Determination of Genocide," Genocide Studies and Prevention 
1 (2006): $57-77$. It is submitted, however, that by mid-2004 a great number of actors were already calling for an international inquiry. See, e.g., Council of the European Union, press release, 26 July 2004, http://www.consilium.europa.eu/ueDocs/cms_Data/docs/pressdata/ en/gena/81554.pdf (accessed 17 January 2007); UN Commission for Human Rights, Report of the United Nations High Commissioner for Human Rights and Follow-Up to the World Conference on Human Rights: Situation of Human Rights in the Darfur Region of the Sudan (7 May 2004), UN Doc. E/CN.4/2005/3, http://www.unhchr.ch/huridocda/huridoca.nsf/e06a5300f90fa0238025668700518ca4/863d14602aa82caec1256ea80038e268/\$FILE/ G0414221.doc (accessed 17 January 2007), paras. 103-4); and Amnesty International, "The Sudan Crisis Q and A" (AI Document AFR 54/089/2004, 16 July 2004). Even the Arab League published, in May 2004, a report of a fact-finding mission documenting that serious atrocities were being committed in Darfur. Given the overall post-Iraq standing of the US government in the UN system, it is more likely that the unilateral US mission made discussions about Darfur more difficult for certain actors at the UN.

22. On this topic see Martin Mennecke and Elisabeth Moltke, "From Rwanda to Darfur-When 'Genocide' Prevents 'Genocide Prevention,”' The Aegis Review on Genocide 1 (2004): 14-17.

23. Outcome Document of the 2005 World Summit, UN Doc. A/RES/60/1 (24 October 2005), http://www.un.org/summit2005/documents.html (accessed 17 January 2007), paras. 138-39; On Protection of Civilians in Armed Conflict, UN Doc. S/RES/1674 (28 April 2006).

24. See Charter of the United Nations, 26 June 1945, http://www.un.org/aboutun/charter/ (accessed 3 January 2007), esp. chapter 7; Constitutive Act of the African Union, 11 July 2000, http://www.africa-union.org/root/au/AboutAU/Constitutive_Act_en.htm (accessed 3 January 2007). Article 4(h) of the AU's Constitutive Act sets out "The right of the Union to intervene in a Member State pursuant to a decision of the Assembly in respect of grave circumstances, namely: war crimes, genocide and crimes against humanity."

25. The genocide question resurfaced when, on 24 May 1999, the ICTY published an indictment against Slobodan Milosevic, president of what was then called the Federal Republic of Yugoslavia, that did not involve charges of genocide. This seemed to undermine some of the arguments Western leaders had been mounting to convince their domestic constituencies of the necessity of using force to resolve the situation in Kosovo. See, e.g., Michael P. Scharf, "The Indictment of Slobodan Milosevic," ASIL Insights, June 1999, http://www.asil.org/insights/insigh35.htm (accessed 3 January 2007).

26. See, e.g., Martin Mennecke, "Genocide in Kosovo?" in Century of Genocide: Critical Essays and Eyewitness Accounts, ed. Samuel Totten, William S. Parsons, and Israel W. Charny, 449-454 (New York: Garland, 2004).

27. Powell, Testimony.

28. For example, Gregory H. Stanton speaks of "legal deniers" and "definitionalist denial" in "Proving Genocide in Darfur: The Atrocities Documentation Project and Resistance to Its Findings" (Genocide Watch, n.d.), http://www.genocidewatch.org/

SudanProvinggenocideinDarfurbyGregoryHStanton.htm (accessed 3 January 2007). Helen Fein has also criticized non-governmental organizations for "avoiding" the term "genocide" during her presentation on the panel "Genocide in Darfur" at the meeting of the International Association of Genocide Scholars, June 2005, in Boca Raton, FL. See also Eric Reeves, "Europe's Indifference to Darfur," The New Republic, 27 October 2006; Reeves repeatedly criticizes European governments as "weaselish" for the same conduct. While much can be said about the lack of leadership displayed by European governments during the Darfur crisis, it seems naïve to believe that the situation would have been much different if all European countries had aligned themselves with the genocide determination of the United States. The decisive stumbling block to a more forceful policy against the government of Sudan was the lack of support for such policy among member states of the African Union.

29. Scheffer has developed and promoted this concept for the last few years. See also, e.g., David Scheffer, "The Future of Atrocity Law," Suffolk Transnational Law Review 
25 (2002): 389-432, and his contribution to the Stockholm International Forum on Genocide Prevention in 2004 in Stockholm, Sweden, http://www.manskligarattigheter.gov.se/ stockholmforum/2004/page1518.html (accessed 17 January 2007).

30. Scheffer, "Genocide and Atrocity Crimes," 237.

31. Colin Powell noted this even before the US genocide determination when visiting Sudan on 30 June 2004. Responding to a question from the press, he remarked that "we see indicators and elements that would start to move you toward a genocide conclusion but we're not there yet. We can find the right label for it later, we have got to deal with it now" (quoted in "Sudanese Refugees Welcome Powell," BBC News, 30 June 2004, http://news.bbc.co.uk/2/hi/africa/3849593.stm (accessed 3 January 2007)). The governments of Sweden and Norway also took this stand in their responses to the Darfur crisis. The UN Commission of Inquiry into Darfur stated that the "crimes against humanity and war crimes that have been committed in Darfur may be no less serious and heinous than genocide": Report of the International Commission of Inquiry on Darfur to the United Nations Secretary-General, UN Doc. S/2005/69 (25 January 2005), http://www.un.org/ News/dh/sudan/com_inq_darfur.pdf (accessed 17 January 2007), para. 522. It is also interesting to note how the Appeals Chamber addressed the concept of genocide as the "crime of crimes" in one of the cases before the ICTR: "The Appeals Chamber remarks that there is no hierarchy of crimes under the Statute, and that all of the crimes specified therein are 'serious violations of international humanitarian law,' capable of attracting the same sentence." Prosecutor v. Kayishema and Ruzindana, Judgment, ICTR95-1-A (1 June 2001), para. 367.

32. Similarly, see Gareth Evans, "Crimes against Humanity: Overcoming Indifference," Journal of Genocide Research 8 (2006): 325-39, 330.

33. See also Frank Chalk, "Atrocity Crimes and the Darfur Crisis" (26 October 2005), http://migs.concordia.ca/AtrocityCrimesOp-Ed.htm (accessed 3 January 2007).

34. The foreign ministries of Ireland, South Africa, and several other countries indicated to me that their view of the genocide question was informed by the report of the UN COI and the ongoing work of the ICC. Communications on file with the author. Juan Méndez, the UN's special adviser on the prevention of genocide, made a similar statement at a press conference on 26 September 2005; he called the debate over the "G-word" a "distraction for the international community... We have spent too much time trying to decide whether genocide happened or not when in fact we should have acted upon these crimes... I think whether they are genocide or not should be left to a court of law." The transcript of this press conference is available at http://www.un.org/Depts/dpa/prev_genocide/ DarfurpressSept2005.pdf (accessed 3 January 2007).

35. The term "atrocity crimes" echoes, to some extent, Raphael Lemkin's original proposal of introducing a norm against "acts of barbarity" to international law. See Lemkin, "Acts Constituting a General (Transnational) Danger Considered as Offences Against the Law of Nations" (1933), trans. James T. Fussell (Prevent Genocide International, 2000), www.preventgenocide.org/lemkin/madrid1933-english.htm (accessed 3 January 2007).

36. Michael Ignatieff, "The Danger of a World without Enemies: Lemkin's Word," The New Republic, 21 February 2001, 25-29, 25.

37. Frank Chalk and Kurt Jonassohn, The History and Sociology of Genocide: Analyses and Case Studies (New Haven, CT: Yale University Press, 1990), 23.

38. This is a sensitive issue. As a starting point, it should be recalled that genocide remains genocide even when the victim group, or some of its factions, has also committed crimes. These crimes cannot serve as a justification for the genocide. At the same time, one should take note of the thought-provoking work of Alan Kuperman, who argues that rebel groups well may provoke, or at least count on, genocidal violence, hoping that this in turn will lead to Western military intervention, in order to achieve their political goals. See Alan J. Kuperman, "Suicidal Rebellions and the Moral Hazard of Humanitarian Intervention," Ethnopolitics 4 (2005): 149-73. 
39. See, e.g., René Lemarchand, "Unsimplifying Darfur," Genocide Studies and Prevention 1 (2006): 1-12, 9-10.

40. The influential International Crisis Group has already started to use the language of "atrocity crimes" in its publications; see, e.g., the recent report Getting the UN into Darfur (12 October 2006), 1, 4, 14. It is also worth noting that a number of governments, in their statements in the UN Security Council, have already, albeit inadvertently, used the term "atrocities" with respect to Darfur; see, e.g., the interventions by Benin, Denmark, the United Kingdom, and France, UN Doc. S/PV/5158 (31 March 2005).

41. Gareth Evans, "Genocide or Crime? Action Speaks Louder Than Words in Darfur," European Voice, 17 February 2005, http://www.europeanvoice.com/archive/ article.asp?id=22228 (accessed 17 January 2007).

42. Quoted in Emily Wax, "US Report Finds Sudan Promoted Killings," Washington Post, 8 September 2004, A17.

43. Raphael Lemkin, Axis Rule in Occupied Europe: Laws of Occupation-Analysis of Government-Proposals for Redress (Washington, DC: Carnegie Endowment for International Peace, 1944), 79.

44. See Office of the Special Adviser on the Prevention of Genocide, "Mandate" (2006), http://www.un.org/Depts/dpa/prev_genocide/mandate.htm (accessed 3 January 2007).

45. Samantha Power, "Raising the Cost of Genocide," Dissent 49, 2 (2002): 85-96, 96. 